\title{
The Government Debt and the Long-Term Interest Rate: Application of the Loanable Funds Model to Greece
}

\author{
Yu Hsing \\ Southeastern Louisiana University
}

\begin{abstract}
This paper extends the open-economy loanable funds model to Greece and finds that a higher government debt/GDP ratio, a higher real short-term rate, a higher percent change in real GDP, a higher expected inflation rate, a higher EU government bond yield, or a higher nominal effective exchange rate increases the Greek government bond yield. In the conventional closed-economy loanable funds model, similar results are found, but the explanatory power is lower. In the conventional open-economy loanable funds model, the percent change in real $G D P$ and the ratio of the net capital inflow to GDP have insignificant coefficients.
\end{abstract}

- JEL Classification: E43, E62, O52

- Keywords: Government Debt, Long-term Interest Rate, Expected Inflation, World Interest Rate, Exchange Rate, Loanable Funds Model

\section{Introduction}

Many countries have experienced declining economic activities, budget shortfalls, and rising government debt due to the worldwide economic recession. Greece is no exception. According to the Economist (2010), Greece faced a government budget deficit of $12.7 \%$ as percent of GDP and a government debt of $112.6 \%$ as percent GDP, which are far above the EU criteria of $3.0 \%$ or less for the deficit/GDP ratio and $60.0 \%$ or less for the debt/GDP ratio.

\footnotetext{
*Corresponding address: Yu Hsing, Ph.D., Department of Management and Business Administration, College of Business, Southeastern Louisiana University, Hammond, LA 70402 USA, Tel/Fax: 001985-549-2081, E-mail:yhsing@selu.edu.

(C2010-Center for Economic Integration, Sejong Institution, Sejong University, All Rights Reserved.
} 
There has been a renewed interest in examining whether more government debt or deficit would raise the long-term interest rate, crowd out some of private expenditures, and dampen economic growth. The literature suggests that more government deficit may or may not lead to a higher interest rate. Feldstein (1982), Hoelscher (1986), Wachtel and Young (1987), Zahid (1988), Thomas and Abderrozak (1988), Miller and Ruseuro (1991), Raynold (1994), Cebula (1989, 1991, 1993, 1997, 1999, 2003), Vamvoukas (1997), Ewing and Yanochik (1999), and Saleh and Harvie (2005) maintain that there is a positive relationship between the government deficit and the interest rate. Kormendi (1983), Hoelscher (1983), Aschauer (1985), Makin (1983), McMillin (1986), Barro (1987), Evans (1985, 1987, 1988), Gupta (1989), Darrat (1989, 1990), Findlay (1990), and Ostrosky (1990) indicate that more government deficit would not lead to a higher interest rate.

Several articles have examined the subject for Greece. Incorporating government debt in the money demand function, Liargovas, Manolas, and Papazoglou (1997) show that more government deficit/debt will raise the interest rate in Greece. Vamvoukas (1997) finds the evidence that more government budget deficits raise the interest rate in Greece. Drakos (2001) indicates that the Greek households treat government bonds as net assets and increase their savings and consumption. Because increased savings do not completely make up for increased government debt, it suggests that the Ricardian equivalence theory does not hold for Greece. Applying the error correction model and several sensitivity tests, Darrat (2002) reveals that more Greek government deficits will not raise the interest rate and suggests that the hypothesis of crowding-out does not hold for Greece. Daniel and Shiamptanis (2008) find that countries like Greece and Italy with a government debt/GDP ratio well above the Maastricht Treaty standard might be not be fiscally safe whereas countries with relatively low government debt/GDP ratio would not face fiscal risk. These previous studies have made significant contributions to the understanding of the relationship between the government deficit or debt and the interest rate in Greece.

Because empirical results in the above studies are inconclusive, this paper attempts to examine the impact of the government debt on the long-term interest rate for Greece and has several focuses. First, the model is extended to incorporate the world long-term interest rate and the exchange rate as potential variables explaining the behavior of international capital flows in supplying loanable funds. Second, the author applies comparative-static analysis in determining the theoretical sign of a change in one of the exogenous variables on the equilibrium 
long-term interest rate. Third, the latest available data are employed in empirical work, and the results would have more policy implications. The paper is organized in the following manner. The theoretical model is presented in the next section. Data sources, the definition and measurement of variables, and empirical results are described and analyzed in the third section. The summary and conclusions are made in the last section.

\section{The Model}

The loanable funds model has been employed in studying the impact of the government deficit or debt on interest rates (Hoelscher, 1986; Tran and Sawhney, 1988; Thomas and Abderrezak, 1988; Cebula, 1988, 1994, 1997a, 1997b, 1998, 1999, 2000, 2003, 2005; Correia-Nunes and Stemitsiotis, 1995; García and Ramajo, 2004; Quayes and Jamal, 2007; Barnes, 2008). Hoelscher (1986) develops a closed-economy loanable funds model, and Cebula (1988, 1994, 1997a, 1997b, 1998, 1999, 2000, 2003) proposes an open-economy loanable funds model by considering the net capital inflow in the supply of loanable funds.

In this paper, the behavior of the net capital inflow is explained by the relative interest rate and the exchange rate (Devereux and Saito, 2006; De Santis and Luhrmann, 2009). As the world long-term interest rate rises (decreases) relative to the Greek long-term interest rate, the net capital inflow to Greece would decrease (increase). As the Greek currency depreciates (appreciates) against other currencies, the net capital inflow to Greece would decrease (increase). Hence, a higher (lower) world long-term interest rate would shift the supply of loanable funds to the left (right) and increase (reduce) the Greek long-term interest rate, and depreciation (appreciation) of the Greek currency would shift the supply of loanable funds to the left (right) and increase (reduce) the Greek long-term interest rate.

Suppose that the demand for loanable funds is negatively affected by the longterm interest rate and positively influenced by the real short-term interest rate, the expected inflation rate, the percent change in real GDP, the nominal effective exchange rate and government debt and that the supply of loanable funds is positively associated with the long-term interest rate, the percent change in real GDP and the nominal effective exchange rate and negatively associated with the real short-term interest rate, the expected inflation rate, and the world long-term interest rate. In the extended open-economy loanable funds model, the demand for and the supply of loanable funds can be expressed as 


$$
\begin{aligned}
& D L F=D(L R, S R, E I, G Y, E X, D E) \\
& S L F=S(L R, S R, E I, G Y, E X, W R)
\end{aligned}
$$

where

DLF $=$ the demand for loanable funds in Greece,

SLF $=$ the supply of loanable funds in Greece,

$\mathrm{LR}=$ the long-term interest rate in Greece,

$\mathrm{SR}=$ the real short-term interest rate in Greece,

$E I=$ the expected inflation rate in Greece,

$\mathrm{GY}=$ percent change in real GDP in Greece,

$\mathrm{EX}=$ the nominal effective exchange rate(An increase means appreciation of the Greek currency.),

$\mathrm{DE}=$ government debt in Greece, and

$\mathrm{WR}=$ the world long-term interest rate.

Solving for the equilibrium long-term interest rate and loanable funds simultaneously gives

$$
\overline{L R}=\overline{L R}(D E, S R, G Y, E I, W R, E X)
$$

The partial derivatives of $\overline{L R}$ with respect to each of the exogenous variables are given by

$$
\begin{gathered}
\partial \overline{L R} / \partial D E=D_{D E} /|J|>0 \\
\partial \overline{L R} / \partial S R=\left(D_{S R}-S_{S R}\right) /|J|>0 \\
\partial \overline{L R} / \partial G Y=\left(D_{G Y}-S_{G Y}\right) /|J|>\text { or }<0 \\
\partial \overline{L R} / \partial E I=\left(D_{E I}-S_{E I}\right) /|J|>0 \\
\partial \overline{L R} / \partial W R=-S_{W R}|J|>0 \\
\partial L R / \partial E X=\left(D_{E X}-S_{E X} /|J|>\text { or }<0\right.
\end{gathered}
$$


where $|J|$ is the Jacobian for the endogenous variables and has a positive value. Theoretically, the equilibrium long-term interest rate has a positive relationship with government debt, the real short-term interest rate, the expected inflation rate and the world long-term interest rate, and it has an ambiguous relationship with the percent change in real GDP or the nominal effective exchange rate.

In comparison, the equilibrium long-term interest rate in the conventional closed-economy and open-economy loanable funds models (Hoelscher, 1986; Cebula, 1988, 1994, 1997a, 1997b, 1998, 1999, 2000, 2003) can be written as

$$
\begin{gathered}
\overline{L R}=\overline{L R}(D E, S R, G Y, E I) \\
\overline{L R}=\overline{L R}(D E, S R, G Y, E I, C I)
\end{gathered}
$$

where CI is the net capital inflow. The sign of CI should be negative as an increase in the net capital inflow to Greece would shift the supply of loanable funds to the right and reduce the equilibrium long-term interest rate.

\section{Empirical Results}

The data were collected from the International Financial Statistics, which is published by the International Monetary Fund. The dependent variable is the Greek government bond yield. The real short-term interest rate is represented by the real Treasury bill rate in Greece to test a potential substitution effect. GY is represented by the percent change in real GDP, which is an index number with 2005 as the base year. DE is measured by the ratio of government debt to GDP. Due to lack of data for the government budget deficit, the ratio of the government budget deficit to GDP is not used in this study. The expected inflation rate is estimated by the average inflation rate of the past four quarters. The EU government bond yield is chosen to represent the world interest rate. EX is represented by the nominal effective exchange rate, which is an index number with 2005 as the base year. An increase means appreciation of the Greek currency. CI is measured by the ratio of the net capital inflow to GDP, where the net capital inflow is the sum of the portfolio, direct and other investments in the financial account. Government debt, the nominal GDP, and the net capital inflow are measured in billions. The sample ranges from 2002.Q2-2009.Q2 for equations (3) and (10) and 2000.Q2-2009.Q1 for equation (11). 
Table 1 reports the estimated regressions and related statistics. Figures in the parenthesis are t-statistics. The $\mathrm{ARCH}(1)$ or $\operatorname{GARCH}(1,0)$ is employed in empirical work because the error variance is found to be a function of the past squared error or the past error variance. In Version I, 76.9\% of the variation in the government bond yield can be explained by the six right-hand side variables. All the coefficients are significant at the $1 \%$ or $10 \%$ level. The government bond yield is positively associated with the ratio of the government debt to GDP, the real shortterm rate, the percent change in real GDP, the expected inflation rate, the EU government bond yield, and the nominal effective exchange rate. To determine whether these time series in Version I are cointegrated, the ADF unit root test on the regression residuals $e_{t}$ is performed. The lag length of one is selected based on the Schwarz information criterion. In the regression $\Delta e_{t}=\alpha e_{t-1}+\beta \Delta e_{t-1}$, the test statistic is estimated to be -6.358 , and the critical value is -2.633 at the $1 \%$ level. Hence, these variables have a long-run equilibrium relationship

In Version II, when the nominal effective exchange rate (NEER) is replaced by the EUR/USD exchange rate, its coefficient is negative and insignificant at the $10 \%$ level, the positive coefficient of the expected inflation rate becomes insignificant at the $10 \%$ level, and other results are similar.

When the conventional closed-economy loanable funds model (Version III) is considered, the value of the adjusted $\mathrm{R}^{2}$ is 0.557 , and the positive coefficients for DE, SR, GY and EI are significant at the $1 \%$ or $5 \%$ level. When the conventional open-economy loanable funds model (Version IV) is considered, the value of the adjusted $\mathrm{R}^{2}$ is 0.540 , the negative coefficient of $\mathrm{CI}$ is insignificant at the $10 \%$ level, the positive coefficient of the percent change in real GDP is insignificant at the $10 \%$ level, and other results are similar to the findings for the closed-economy loanable funds model in Version III. Hence, the inclusion of the world long-term interest rate and the exchange rate would improve the explanatory power of the regression and better capture the behavior of international capital flows.

In absolute values, the coefficients for DE, SR, GY and EI in Versions I and II are smaller than those in Versions III and IV. In Version I, if the coefficient of the EU government bond yield increases 1 percentage point, the government bond yield will rise 1.041 percentage points; and if the expected inflation rate rises 1 percentage point, the government bond yield will increase 0.595 percentage points. In Version II, the coefficient of the EU government bond yield is 1.073, which is similar to the coefficient of the EU government bond yield in Version I. In Versions III and IV, the estimated coefficients have similar values, and the coefficients of the 
Table 1. Estimated Regressions of the Government Bond Yield (LR) for Greece based on the Extended Loanable Funds Model

\begin{tabular}{|c|c|c|c|c|}
\hline Variable & $\mathrm{I}$ & II & III & IV \\
\hline $\mathrm{C}$ & $\begin{array}{c}-2.142 \\
(-5.375)\end{array}$ & $\begin{array}{c}-4.074 \\
(-7.666)\end{array}$ & $\begin{array}{r}-3.648 \\
(-1.927)\end{array}$ & $\begin{array}{l}-2.842 \\
(-1.350)\end{array}$ \\
\hline $\mathrm{DE}$ & $\begin{array}{c}0.002 \\
(10.518)\end{array}$ & $\begin{array}{c}0.011 \\
(7.750)\end{array}$ & $\begin{array}{l}0.018 \\
(3.685)\end{array}$ & $\begin{array}{c}0.016 \\
(3.362)\end{array}$ \\
\hline SR & $\begin{array}{c}0.098 \\
(23.804)\end{array}$ & $\begin{array}{c}0.081 \\
(3.011)\end{array}$ & $\begin{array}{l}0.404 \\
(6.596)\end{array}$ & $\begin{array}{l}0.425 \\
(6.644)\end{array}$ \\
\hline GY & $\begin{array}{c}0.001 \\
(1.855)\end{array}$ & $\begin{array}{r}0.016 \\
(3.205)\end{array}$ & $\begin{array}{l}0.031 \\
(2.163)\end{array}$ & $\begin{array}{c}0.026 \\
(1.574)\end{array}$ \\
\hline EI & $\begin{array}{c}0.595 \\
(12.797)\end{array}$ & $\begin{array}{c}0.270 \\
(1.409)\end{array}$ & $\begin{array}{l}1.577 \\
(6.356)\end{array}$ & $\begin{array}{l}1.516 \\
(1.877)\end{array}$ \\
\hline WR & $\begin{array}{c}1.041 \\
(59.122)\end{array}$ & $\begin{array}{l}1.073 \\
(8.847)\end{array}$ & & \\
\hline REER & $\begin{array}{c}0.009 \\
(3.466)\end{array}$ & & & \\
\hline EUR/USD & & $\begin{array}{c}-0.482 \\
(-1.223)\end{array}$ & & \\
\hline CI & & & $(-0.856)$ & -0.011 \\
\hline R-squared & 0.820 & 0.909 & 0.631 & 0.632 \\
\hline $\begin{array}{l}\text { Adjusted R- } \\
\text { squared }\end{array}$ & 0.769 & 0.883 & 0.557 & 0.540 \\
\hline $\begin{array}{l}\text { Akaike inform. } \\
\text { criterion }\end{array}$ & -2.024 & -0.306 & 1.435 & 1.512 \\
\hline Schwarz criterion & -1.632 & 0.086 & 1.740 & 1.864 \\
\hline Sample period & $\begin{array}{l}\text { 2002.Q2- } \\
\text { 2009.Q2 }\end{array}$ & $\begin{array}{l}\text { 2002.Q2- } \\
\text { 2009.Q2 }\end{array}$ & $\begin{array}{l}\text { 2002.Q2- } \\
\text { 2009.Q2 }\end{array}$ & $\begin{array}{l}\text { 2002.Q2- } \\
\text { 2009.Q1 }\end{array}$ \\
\hline $\mathrm{N}$ & 39 & 39 & 39 & 36 \\
\hline
\end{tabular}

Notes: $\mathrm{C}$ is the constant. DE is the ratio of the government debt to GDP. SR is the real Treasury bill rate. GY is the percent change in real GDP. EI is the expected inflation rate. WR is the EU government bond yield. NEER is the nominal effective exchange rate. EUR/USD is the euro/dollar exchange rate. $\mathrm{CI}$ is the ratio of the net capital inflow to GDP. The ARCH(1) model is employed in Version I, and the $\operatorname{GARCH}(1,0)$ model is used in Versions II, III, and IV.

real Treasury bill rate and the expected inflation rate are larger than other coefficients. For example, a 1 percentage point increase in the expected inflation will raise the government bond yield by 1.577 percentage points in Version III and 1.516 percentage points in Version IV. A 1 percentage point increase in the real Treasury bill rate will cause the government bond yield to rise by 0.404 percentage points in Version III and 0.425 percentage points in Version IV. The insignificant 
coefficient of the EUR/USD exchange rate in Version II suggests that the nominal effective exchange rate used in Version I is a better measure than the EUR/USD exchange rate. Among these different versions, Version I is a better specification than the other three versions because all the coefficients are significant and have the expected sign and because the regression has smaller values of Akaike information criterion and Schwarz criterion.

In comparison, the major finding that a higher government debt/GDP ratio will raise the government bond yield is consistent with the findings from Liargovas, Manolas, and Papazoglou (1997) and Vamvoukas (1997) but is in contrast with the result from Darrat (2002).

\section{Summary and Conclusions}

This paper has applied an extended open-economy loanable funds model to examine whether the Greek long-term interest rate would be affected by government debt and other related macroeconomic variables. The results show that more government debt as a percent of GDP would raise the government bond yield and that a higher real short-term interest rate, a higher percent change in real GDP, a higher expected inflation rate, a higher EU government bond yield, and a higher effective nominal exchange rate would raise the Greek government bond yield. In the conventional closed-economy loanable funds model, similar results are found, but the explanatory power is lower. In the conventional open-economy loanable funds model, except that the coefficient of the ratio of the net capital inflow to GDP and the expected inflation rate are insignificant at the $10 \%$ level, and other results are similar to those for the closed-economy loanable funds model. Hence, the world long-term interest rate and the nominal effective exchange rate incorporated in this study increase the explanatory power for the behavior of the Greek government bond yield.

There are several policy implications. The Greek potential debt crisis has given the euro area a new challenge on how to solve it without endangering the fiscal position of other member countries (Cohen, 2010). If the debt crisis is not solved properly, the cost for issuing the euro area government bond may rise. The euro area needs to take effective measures to request its member countries to pursue fiscal discipline and to follow Maastricht Treaty's criteria of not exceeding $60 \%$ for the ratio of government debt to GDP and 3\% for the ratio of the budget deficit to GDP. The significant coefficient of the ratio of the government debt to GDP 
implies that pursuing the debt-financed expansionary fiscal policy to stimulate the economy would raise the long-term government bond yield, reduce the magnitude of the government spending multiplier, and crowd out part of private spending. In the extended open-economy loanable funds model, the long-term world long-term interest rate and the exchange rate need to be considered as international investors search for better returns in determining the supply of loanable funds to Greece or other countries. The insignificant coefficient of the ratio of the net capital inflow to GDP suggests that its role may be replaced by the world long-term interest rate and the nominal effective exchange rate.

There may be potential areas for future research. After the global recession, the regressions may need to be re-estimated to determine whether the results are robust. The expected inflation rate may be constructed by other methodologies. Other theories of interest rate determination such as an extended IS-LM model may be considered, although there are issues and problems in its application (Romer, 2000).

Received 16 February 2010, Revised 21 October 2010, Accepted 26 October 2010

\section{References}

Aschauer, D. A. (1989), Does Public Capital Crowd out Private Capital?, Journal of Monetary Economics, 25, pp. 171-88.

Barnes, B. J. (2008), A Cointegrating Approach to Budget Deficits and Long-Term Interest Rates, Applied Economics, 40, pp. 127-33.

Barro, R. J. (1974), Are Government Bonds Net Wealth?, Journal of Political Economy, 82, pp. 1095-117.

Barro, R. J. (1987), Government Spending, Interest Rates, Prices, and Budget Deficits in the United Kingdom 1701-1918, Journal of Monetary Economics, 20, pp. 221-47.

Barro, R. (1989), The Ricardian Approach to Budget Deficits, Journal of Economic Perspectives, 3, pp. 37-54.

Barth, J. R., Iden, G. R., Russek, F. S. (1984), Do Federal Budget Deficits Really Matter? Contemporary Policy Issues, 3, pp. 79-95.

Barth, J. R., Iden, G. R., Russek, F. S. (1985), Federal Borrowing and Short-Term Interest Rates: comment, Southern Economic Journal, 52, pp. 554-59.

Boskin, M. J. (1988), Consumption, Saving, and Fiscal Policy, American Economic Review, 78, pp. 401-7.

Bovenberg, A. L. (1988), Long-Term Interest Rates in the US, International Monetary Fund Staff Papers, 35, pp. 382-90.

Cebula, R. J. (1988), Federal Government Budget Deficits and Interest Rates: An 
Analysis for the United States 1955-1984, Public Finance, 43, pp. 337-48.

Cebula, R. J. (1991), A Note on Federal Budget Deficits and the Term Structure of Real Interest Rates in the United States, Southern Economic Journal, 57, pp. 1170-3.

Cebula, R. J. (1997a), The Impact of Net International Capital Flows on Nominal LongTerm Interest Rates in France, Atlantic Economic Journal, 25, pp. 179-90.

Cebula, R. J. (1997b), An Empirical Note on the Impact of the Federal Budget Deficit on Ex Ante Real Long-Term Interest Rates, 1973-1995 Southern Economic Journal, 63, pp. 1094-99.

Cebula, R. J. (1998), Budget Deficits and Long-Term Interest Rates: 1973-1991, International Advances in Economic Research, 4, pp. 374-88.

Cebula, R. J. (1999), Budget Deficits, Capital Flows, and Long-Term Interest Rates: Cointegration Findings for the UK, International Advances in Economic Research, $\mathbf{5}$, pp. 374-88.

Cebula, R. J. (2000), Impact of Budget Deficits on Ex Post Real Long-Term Interest Rates, Applied Economics Letters, 7, pp. 177-9.

Cebula, R. J. (2003), Budget Deficits and Interest Rates in Germany, InternationalAdvance in Economic Research, 9, pp. 64-8.

Cebula, R. J. (2005), New Historical Evidence on the Impact of Budget Deficits in the U.S. on Long Term High Grade Corporate Bond Interest Rate Yields, RISEC: International Review of Economics and Business, 52, pp. 103-11.

Cebula, R. J., Belton, W. J. (1993), Government Budget Deficits and Interest Rates in the United States: Evidence for Closed and Open Systems Put into Perspective: 19551989, Public Finance, 48, pp. 188-209.

Cebula, R. J., Koch, J. V. (1989), An Empirical Note on Deficits, Interest Rates, and International Capital Flows, Quarterly Review of Economics and Business, 29, pp. 121-7.

Cebula, R. J., Koch, J. V. (1994), Federal Budget Deficits, Interest Rates, and International Capital Flows: A Further Note, Quarterly Review of Economics and Finance, 34, pp. $117-20$.

Cebula, R. J., Saltz I. S. (1992), Central Government Budget Deficits and Ex Ante Real Long Term Interest Rates in the United Kingdom: An Empirical Note, International Review of Economics and Business, 39, pp. 479-84.

Cebula, R. J., Saltz I. S. (1993), Budget Deficits and Real Interest Rates in the United States, Indian Economic Journal, 41, pp. 74-82.

Cohen, A. (2010), EU Leaders Meet to Avoid Greek Crisis, Wall Street Journal, Feb. 15, http://online.wsj.com/article/SB100014240527487035257045750612404698 61942.html.

Correia-Nunes, J., Stemitsiotis L. (1995), Budget Deficit and Interest Rates: Is There a Link? International Evidence, Oxford Bulletin of Economics and Statistics, 57, pp. 425-49.

Daniel, B., Shiamptanis, C. (2008), Fiscal Risk in a Monetary Union, University at Albany, SUNY, Department of Economics, Discussion Papers. 
Darrat, A. F. (1989), Fiscal Deficits and Long-Term Interest Rates: Further Evidence from Annual Data, Southern Economic Journal, 56, pp. 363-73.

Darrat, A. F. (1990), Structural Federal Deficits and Interest Rates: Some Causality and Cointegration Tests, Southern Economic Journal, 56, pp. 752-9.

Darrat, A. F. (2002), On Budget Deficits and Interest Rates: Another Look at the Evidence, International Economic Journal, 16, pp. 19-29.

De Santis, R. A., Luhrmann M. (2009), On the Determinants of Net International Portfolio Flows: A Global Perspective, Journal of International Money and Finance, 28, pp. 880-901.

Devereux, M. B., Saito M. (2006), A Portfolio Theory of International Capital Flows, CEPR Discussion Papers: 5746.

Drakos, K. (2001), Testing the Ricardian Equivalence Theorem: Time Series Evidence from Greece, Journal of Economic Development, 26, pp. 149-60.

Evans. P. (1985), Do Large Deficits Produce High Interest Rates?, American Economic Review, 75, pp. 68-87.

Evans, P. (1987), Do Budget Deficits Raise Nominal Interest Rates? Evidence from Six Countries, Journal of Monetary Economics, 20, pp. 281-300.

Evans. P. (1988), Are Government Bonds Net Wealth? Evidence for the United States, Economic Inquiry, 26, pp. 551-66.

Ewing, B. T., Yanochik M. A. (1999), Budget Deficits and the Term Structure of Interest Rates in Italy, Applied Economics Letters, 6, pp. 199-201.

Feldstein, M. (1982), Government Deficits and Aggregate Demand, Journal of Monetary Economics, 9, pp. 1-20.

Findlay, D. W. (1990), Budget Deficits, Expected Inflation and Short-Term Real Interest Rates: Evidence for the US, International Economic Journal, 4, pp. 41-53.

Gale, W. G., Orszag P. R. (2004), Budget Deficits, National Saving, and Interest Rates, Brookings Papers on Economic Activity, 2, pp. 101-210.

García, A., Ramajo J. (2004), Budget Deficit and Interest Rates: Empirical Evidence for Spain, Applied Economics Letters, 11, pp. 715-18.

Gupta, K. L. (1989), Budget Deficits and Interest Rates in the US, Public Choice, 60, pp. 87-92.

Hartman, H. C. (2007), Deficit-Related Explanations for the US Interest Rate Conundrum, Applied Economics Letters, 14, pp. 261-5.

Hoelscher, G. (1983), Federal Borrowing and Short-Term Interest Rates, Southern Economic Journal, 50, pp. 319-33.

Hoelscher, G. (1986), New Evidence on Deficits and Interest Rates, Journal of Money, Credit, and Banking, 18, pp. 1-17.

Kormendi, R. C. (1983), Government Debt, Government Spending, and Private Sector Behavior, American Economic Review, 73, pp. 994-1010.

International Monetary Fund (2009), IMF Executive Board Concludes 2009 Article IV Consultation on Euro Area Policies, Public Information Notice (PIN) No. 09/95, July 30, http://www.imf.org/external/np/sec/pn/2009/pn0995.htm. 
Laubach, T. (2009), New Evidence on the Interest Rate Effects of Budget Deficits and Debt, Journal of the European Economic Association, 7, pp. 858-85.

Liargovas, P., Manolas, G., Papazoglou, C. (1997), The Relationship between Government Budget Deficits and Interest Rates in Greece, RISEC: International Review of Economics and Business, 44, pp. 807-17.

Makin, J. H. (1983), Real Interest, Money Surprises, Anticipated Inflation and Fiscal Deficits, Review of Economics and Statistics, 65, pp. 374-84.

McMillan, W. D. (1986), Federal Deficits and Short-Term Interest Rates, Journal of Macroeconomics, 8, pp. 403-22.

Miller. S. M., Russek, F. S. Jr. (1991), The Temporal Causality between Fiscal Deficits and Interest Rates, Contemporary Policy Issues, 9, pp. 12-23.

Ostrosky, A. L. (1990), Federal Government Budget Deficits and Interest Rates: Comment, Southern Economic Journal, 56, 802-3.

Plosser, C. I. (1982), Government Financing Decisions and Asset Returns, Journal of Monetary Economics, 9, pp. 325-52.

Plosser, C. I. (1987), Fiscal Policy and the Term Structure, Journal of Monetary Economics, 20, pp. 343-67.

Quayes, S., Jamal A. M. M. (2007). Budget Deficits and Interest Rates: the US Evidence since 1946, Singapore Economic Review, 52, pp. 191-200.

Raynold, P. (1994), The Impact of Government Deficits When Credit Markets are Imperfect: Evidence from the Interwar Period, Journal of Macroeconomics, 16, pp. $55-76$.

Saleh, A. S., Harvie C. (2005), The Budget Deficit and Economic Performance: A Survey, Singapore Economic Review, 50, pp. 211-43.

Seater, J. J. (1985), Does Government Debt Matter? A Review, Journal of Monetary Economics, 16, pp. 121-31.

The Economist (2010), A Very European Crisis: The Sorry State of Greece's Public Finances Is a Test Not Only for the Country's Policymakers But Also for Europe's, Feb $4^{\text {th }}$. http:/ /www.economist.com/world/europe/displaystory.cfm?story_id=15452594.

Thomas Jr. L. B., Abderrezak A. (1988), Long-Term Interest Rates: The Role of Expected Budget Deficits, Public Finance Quarterly, 1, pp. 341-56.

Tran, D. T., Sawhney B. L. (1988), Government Deficits, Capital Flows, and Interest Rates, Applied Economics, 20, pp. 753-765.

Vamvoukas, G. A. (1997), A Note on Budget Deficits and Interest Rates: Evidence from A Small, Open Economy, Southern Economic Journal, 63, pp. 803-11.

Wachtel, P., Young J. (1987), Deficit Announcements and Interest Rates, American Economic Review, 5, pp. 1007-12.

Wang, Z., Rettenmaier A. J. (2008), Deficits, Explicit Debt, Implicit Debt, and Interest Rates: Some Empirical Evidence, Southern Economic Journal, 75, pp. 208-22.

Zahid, K. H. (1988), Government Budget Deficits and Interest Rates: The Evidence since 1971 Using Alternate Deficit Measures, Southern Economic Journal, 3, 725-31. 